ARAŞTIRMA MAKALESI / RESEARCH ARTICLE

\title{
SOCIAL TRANSFERS AND UNEMPLOYMENT DURATION: AN EMPIRICAL EVIDENCE OF THE EU AND TURKEY ${ }^{*}$
}

\author{
SOSYAL TRANSFERLER VE İŞSIZZLİK SÜRESİ: AB VE TÜRKİYE'DEN \\ AMPIRİK BİR KANIT
}

Fadime İrem DOĞAN ${ }^{* *}$ (D)

\section{Özet}

Bu çalışma; Türkiye ve Avrupa Birliği (AB) olmak üzere iki farklı emek piyasası çapında, üç farklı ülkede (Türkiye, Hollanda ve İspanya) sosyal transferlerin iş gücüne katılımına olan etkisini incelemeyi amaçlamaktadır. Karşılaştırmalı analizlerde, odak iki farklı periyodun etkisine bakmaktır. İşsiz olma durumundan istihdama katılma durumu Hızlandırılmış Başarısızlık Süresi (AFT) modeli kullanılarak, iki periyottan oluşan (2006 -09 ve 2011 -14), aylık olarak bölünmüş (her periyotta 48 ay olmak üzere) Gelir ve Yaşam Koşulları Anketi (GYKA) panel veri seti ile gerçekleştirilmiştir. 2006 - 09 periyodu için sonuçlar, Hollanda hariç, tüm ülkelerde sosyal transfer alımının işsizlik süresini artırdığı yönündedir. 2011 - 14 periyodu için ise tüm ülkelerde sosyal transferlere bakıldığında, çeşitli sosyal transferleri (eğitim, malullük, yaşlllık, dul ve yetim, vb.) alan bireylerin işsizlikten çıkma durumu olasılığının daha uzun sürdüğü sonucuna varılmıştır.

Anahtar Kelimeler: Sosyal Transferler, İşü̈cü Arzı, İşsizlik Süresi, Emek Piyasası

JEL Sinıflandırmasi: J01, J22, J40, J64

\begin{abstract}
This study investigates the impact of social transfers on labor force participation in three countries (Turkey, the Netherlands and Spain) across two different labor markets-namely, Turkey and the EU. In conducting the comparative analysis, the focus is on impacts across different periods.

* This article builds on author's Ph.D. dissertation entitled “The Impact of Social Transfers on Labor Supply: A Comparative Analysis of Turkey and the EU”. Also, this study is the extended version of Doğan (2019).

** Email: irem.dogan@altinbas.edu.tr, Altinbas University, Department of International Trade, Istanbul, Turkey
\end{abstract}


Specifically, the study assesses exit from unemployment to employment through an Accelerated Failure Time (AFT) model, drawing on panel data from the Income and Living Conditions Survey (SILC and EUSILC) over two periods (2006-09 and 2011-14 ${ }^{1}$ ) broken down by month (i.e. 48 months in each period). In the 2009-09 period, the empirical results show that in all three countries studied, receipt of social transfers prolongs the duration of unemployment, except for the Netherlands, where the opposite is true. These findings regarding social transfers also indicate that the probability of leaving unemployment is higher for those receiving a variety of transfers (education, disability, old age, survivors, etc.) for all countries in the 2011-14 period.

Keywords: Social Transfers, Labor Supply, Unemployment Duration, Labor Markets JEL Classification: J01, J22, J40, J64

\section{Introduction}

Social transfers constitute all the goods and services provided by a public authority to citizens whose living conditions are assessed as being below a certain minimum standard. They aim to raise individual living conditions above the minimum to improve social welfare as a whole. In practice, most countries offer the option to meet the household budget via working or receipt of allowances (or a mix of the two), and this choice has a significant impact on labor supply. The structure of the social transfer system in a given country reflects the particular assessment of social welfare and entitlement/need obtaining there. The key components of the social transfer system are "what is required in order to qualify for benefits and how many persons are entitled to be covered by the program, determined how much is paid, and for how long, and established which actors carry the costs and in what proportions ${ }^{2}$ ”.

The impact of social transfers on the macroeconomic variables of labor supply have been much debated in the seminal works ${ }^{3}$. Krueger and Meyer $(2002)^{4}$ were among the first to point out that employees are more likely to spend time out of work as the generosity of unemployment insurance (UI) and workers' compensation insurance increases. In a similar vein, the impact of (insufficient) social transfers-either low level or no transfers at all-on labor conditions has come under scrutiny recently as a crucial global topic ${ }^{5}$. The consensus in the literature is that social transfers do influence individual decisions concerning labor market participation.

1 The choice of these periods primarily has to do with the controlling for the impact of severe economic crisis.

2 Esser, I., Ferrarini, T., Nelson, K., Palme, J., \& Sjöberg, O. (2013). Unemployment benefits in EU member states.

3 Heckman, J. (1974). Shadow prices, market wages, and labor supply. Econometrica: journal of the econometric society, 679-694., Krueger, A. B., \& Pischke, J. S. (1992). The effect of social security on labor supply: A cohort analysis of the notch generation. Journal of labor economics, 10(4), 412-437., Siebert, H. (1997). Labor market rigidities: at the root of unemployment in Europe. The Journal of Economic Perspectives, 11(3), 37-54., Krueger, A. B., \& Meyer, B. D. (2002). Labor supply effects of social insurance. Handbook of public economics, 4, 2327-2392.

4 Krueger, A. B., \& Meyer, B. D. (2002). Labor supply effects of social insurance. Handbook of public economics, 4, 23272392.

5 Bargain, O., \& Doorley, K. (2013). Putting structure on the RD design: social transfers and youth inactivity in France., Arranz, J. M., \& García-Serrano, C. (2014). Duration and recurrence of unemployment benefits. Journal of Labor Research, 35(3), 271-295., Tatsiramos, K., \& Ours, J. C. (2014). Labor market effects of unemployment insurance design. Journal of Economic Surveys, 28(2), 284-311., Yildirim, J., \& Dal, S. (2016). Social Transfers and Labor Force Participation Relation in Turkey: A Bivariate Probit Analysis. Emerging Markets Finance and Trade, 52(7), 1515-1527., Edisis, A. T. (2016). The Effect of Unemployment Insurance on Temporary Help Services Employment. Journal of Labor 
Analysis of the impact of UI on the transition from unemployment to employment for different countries has also offered crucial insights. Filiz $(2017)^{6}$ has examined the impact of UI benefit generosity on benefit duration and labor market transitions in Turkey between 2002 and 2012 by employing a regression discontinuity approach. The author concludes that unemployment duration increases by approximately 0.7 weeks per additional week of UI benefit offered. Another study by Yldirım and Dal $(2016)^{7}$ investigates the link between labor force and social assistance program participation in Turkey, drawing on the 2011 household budget survey data and employing a bivariate probit model. Their research suggests that if individuals work more, they are less likely to participate in any social transfer program. Lachowska et al. $(2016)^{8}$ conducted a study on long-term labor market outcomes in the United States, drawing on experimental data from the Washington Alternative Work Search (WAWS) project. They conclude that a work test for UI decreases the probability of a transition from unemployment to employment. Hägglund and Bächmann (2017) ${ }^{9}$ investigate women and men's transition from unemployment to employment in Germany for the period of 1993-2010. They find that males are more likely than females to make the transition from unemployment to employment ${ }^{10}$. In an older study, Graversen and Van Ours (2008) ${ }^{11}$ investigates the effect of Denmark's mandatory activation program on unemployed people. This study, however, did not test for gender differences. They arrive at the conclusion the unemployment duration of people who are exposed to activation measures is shortened compared to those who are not. In addition, participants in an activation program were more likely to find jobs. Gabriel et al. (2017) ${ }^{12}$ study the duration of unemployment in Botoşani County, Romania with administrative data from 2012 to 2015. Employing a Cox regression model, the authors find that unemployment benefits and location of residence combined did affect the duration of individual unemployment. Using the Cox proportional hazard model, Dănăcică and Mazilescu $(2014)^{13}$ examine the probability of males being

Research, 37(4), 484-503., Filiz, E. S. (2017). The Effect of Unemployment Insurance Generosity on Unemployment Duration and Labor Market Transitions. LABOUR, 31(4), 369-393., Morrissey, T. W. (2017). Child care and parent labor force participation: a review of the research literature. Review of Economics of the Household, 15(1), 1-24., Ahmad, N., Svarer, M., \& Naveed, A. (2019). The Effect of Active Labour Market Programmes and Benefit Sanctions on Reducing Unemployment Duration. Journal of Labor Research, 1-28., Arendt, J. N., \& Kolodziejczyk, C. (2019). The Effects of an Employment Bonus for Long-Term Social Assistance Recipients. Journal of Labor Research, 1-16.

6 Filiz, E. S. (2017). The Effect of Unemployment Insurance Generosity on Unemployment Duration and Labor Market Transitions. LABOUR, 31(4), 369-393.

7 Yildirim, J., \& Dal, S. (2016). Social Transfers and Labor Force Participation Relation in Turkey: A Bivariate Probit Analysis. Emerging Markets Finance and Trade, 52(7), 1515-1527.

8 Lachowska, M., Meral, M., \& Woodbury, S. A. (2016). Effects of the unemployment insurance work test on long-term employment outcomes. Labour Economics, 41, 246-265.

9 Hägglund, A. E., \& Bächmann, A. C. (2017). Fast lane or down the drain? Does the occupation held prior to unemployment shape the transition back to work?. Research in Social Stratification and Mobility, 49, 32-46.

10 They also focus on the Hartz reforms to analyze unemployment and re-employment transitions under the benefits system. The Cox proportional hazard estimates show that the type and duration of benefit affect transition from unemployment to employment. Moreover, the probability of transition depends on education level and past job experience.

11 Graversen, B. K., \& Van Ours, J. C. (2008). How to help unemployed find jobs quickly: Experimental evidence from a mandatory activation program. Journal of Public economics, 92(10-11), 2020-2035.

12 Gabriel, D., Brigitte, S. C., \& Elisabeta, J. (2017). Estimation of Unemployment Duration in Botoşani County Using Survival Analysis. Ovidius University Annals, Series Economic Sciences, 17(1).

13 Dănăcică, D. E., \& Mazilescu, R. (2014). Long-term unemployment spells and exit states of men in Romania and 
reemployed in Hungary and Romania between 2008 and 2010. The authors find that the probability of re-employment for Hungarian males decreases when their duration of unemployment increases (up to 2 years unemployment).

Against this backdrop, this article researches the impact of social transfers on labor supply in two different labor markets-Turkey and the EU. The investigation also focuses on the impacts across different periods by examining the probability of exit from unemployment to employment. It draws on a panel data from the Income and Living Conditions Surveys (SILC and EU-SILC) published by TurkStat and Eurostat over two periods (2006-2009 and 2011-2014). The empirical results demonstrate that in all three countries across bother periods receiving social transfers prolongs the duration of unemployment. In the 2006-2009 period, social transfers, as a total is statistically significant. Although in the case of the Netherlands, the more individuals receive social transfers, the shorter their unemployment duration, the results for the rest of the countries indicate that social transfers as a whole prolong the unemployment spell. The findings regarding total social transfers show that the probability of leaving unemployment is longer for those receiving a variety of transfers (education, disability, old age, survivors, etc.) for all countries in the 2011-2014 period.

The remainder of the paper is structured as follows. Section 2 details the nature of the social transfer systems in Turkey and the EU. Section 3 presents the data used for the analysis, and some basic descriptive statistics regarding the sample. Section 4 details the empirical strategy employed. The estimation results are then presented in section 5 . The paper concludes with a short summary of the key findings and suggestions for future research.

\section{Social Transfers in Turkey and the EU}

This section describes the social transfer systems in the three country cases studied-namely Turkey and the two EU cases: the Netherlands and Spain. In addition to general socio-economic characteristics, the complexity of its structure of social services is an indication of a country's level of development. As a developing country, Turkey's social system of social assistance is rudimentary and can only provide basic social support to the most needy citizens. Turkey's Law No. 2828, defines social services as those provided through formal programs to the most marginalized individuals or households to boost living conditions. Despite Turkey's status as a developing country, its social services system covers a range of sectors and different population groups: the elderly, the handicapped, families, health, education, housing, and unemployment ${ }^{14}$.

The Turkish social security system consists of two pillars. The first pillar comprises three main institutions - the Social Insurance Institution (Sosyal Sigortalar Kurumu, SSK), the Social Security of Craftsmen and self-employed (Bağ-Kur), and the Retirement Fund (Emekli Sandığı, ES). In 2006 all these institutions were unified under the Social Security Institution (Sosyal Güvenlik Kurumu, SGK). The second pillar consists of the Individual Pension System (Bireysel Emeklilik Sistemi), which is

Hungary. Procedia Economics and Finance, 8, 236-245.

14 Isıkhan, V. (2009). THE ASPECT OF SOCIAL SERVICES IN TURKEY. Serviço Social \& Realidade, 17(2), 156-171. 
managed by individuals privately. In Turkey old age, disability, and survivors' benefits belong to the social insurance system and it covers all employees, which are civil servants, self-employed persons, and full-time household workers. The government's total contribution to the fund is $25 \%$ while employers pay $11 \%$ monthly. Individuals who reach the age of 60 (men) and age of 58 (women) are eligible for old age benefits. In terms of disability pensions, individuals are only eligible if they have lost $60 \%$ or more of working capacity and have already paid contributions for at least 1,080 days with 10 years of coverage. Old age or disability pension is eligible to deceased with 900 days of paid contribution with 5 years of coverage for survivor pension. Funeral grants are paid to the family of the deceased. Sickness and maternity consist of social insurance (cash benefits) and universal (medical benefits) system of the type of the program. All citizens of Turkey-including refugees, foreigners with a residence permit of one year or more, homeless people, and foreign students are eligible for medical benefits-and employees and their dependent family members have the right to apply for cash and medical benefits. Individuals must have completed contribution in the last 120 days of employment and have completed contributions for at least 600 days in the three years before unemployment to be able to apply for the UB (unemployment benefit). In late 2018, the Turkish Employment Agency announced that individuals are not obliged to fulfill 120 days of employment before unemployment as a rule to apply for the $\mathrm{UB}^{15}$.

In the EU, competence for social protection systems is retained by the individual Member States, while policies related to competition and the single market (including the labor market) are dealt with at the EU level ${ }^{16}$. Member states are expected to take action regarding their social welfare systems according to their social, economic, and national structures.

In the Netherlands, old age, disability and survivors' pensions covered all the Netherlands residents and people who work in the Netherlands working up to the age of 65 and 6 months over the period of the present study (the age limit will rise to 67 in 2021). Sickness and maternity coverage is provided mostly through private operators. Medical and long-term care benefits cover all people legally resident in the country as well as those conducting regular professional activity in the Netherlands but living outside the country (i.e. in close neighboring countries such as Germany, Luxembourg and Belgium since it is possible to live in Germany and work in the Netherlands easily because the Netherlands is such a tiny country and the other countries are so close and you can drive from one to the other in under an hour or so. So too with Belgium and Luxembourg and this is how the Netherlands would cover people living abroad in this way.). And all employed individuals have been entitled to receive unemployment benefit since 1987. Moreover, individuals must have been actively contributing for at least 26 of the 36 weeks before becoming unemployed and the duration of the payment is the same number of months as the length of working history calculated in years and cannot be higher than those months.

15 Social Security Administration. (2016). Social Security Programs Throughout the World: Europe, 2016.

16 Scharpf, F. W. (2002). The European social model. JCMS: Journal of Common Market Studies, 40(4), 645-670., Alsasua, J., Bilbao-Ubillos, J., \& Olaskoaga, J. (2007). The EU integration process and the convergence of social protection benefits at national level. International Journal of Social Welfare, 16(4), 297-306. 
In Spain, old age, disability, and survivors covered all individuals working up to the age of 65 and 4 months over the period of the present study (the age limit will rise to 67 in 2027). Sickness and maternity coverage are set for employed, specific self-employed individuals. Pensioners are eligible for medical benefits. In terms of work injury, all employers are entitled to receive it since 1994. Regulatory framework of unemployment benefit works since 1985 and industry, commerce, and services sector workers are covered. In Spain, individuals must contribute to the system for at least 360 days in the 6 years before becoming unemployed and the duration of the payment is between 120 and 720 days depending on the premiums paid ${ }^{17}$.

\section{Data and Descriptive Statistics}

The data for the Turkish case comes from the SILC, a four-year panel survey conducted by TurkStat. For the two EU countries, the four-year panel survey EU-SILC, published by Eurostat for the periods of 2006-2009 and 2011-2014 are used ${ }^{18}$. TurkStat has accredited its studies with the EU and so the SILC dataset has matched the Eurostat survey since 2006 in terms of data collection and methodological protocols. Since the number of unemployment benefit recipients is relatively small and time-series analysis of unemployment spells needs to be quite granular (i.e. since people can be unemployed for short periods), the annual observations have been converted into monthly data (48 months in total).

As laid out above, two EU countries were chosen for analysis: the Netherlands and Spain. One reason is that these cases were chosen on the basis of population statistics (i.e. Spain is one of the most populous continental European country). Spain was one of the five EU Member States most affected by the 2010 European sovereign debt crisis. Unemployment reached more than $20 \%$ during the crisis. The situation was even worse for young people; youth unemployment rose as high as $45 \%$. Turkey has been following in the steps of the Spanish labor market but 25 years behind in terms of its institutionalization, labor market structure, etc. The Netherlands has a "hybrid" labor market type ${ }^{19}$. The Netherlands may have a smaller population, but it has the second-lowest unemployment rate in the EU (after Germany). Moreover, the Dutch labor market has been liberalized in recent years ${ }^{20}$.

As far as unemployment spells are concerned, the definitions are as follows. The beginning of a job search (meaning "being unemployed") and the end of a job search (meaning "being employed") gives us the unemployment spell of an individual. The length of the unemployment spell indicates the unemployment duration ${ }^{21}$.

17 Social Security Administration. (2016). Social Security Programs Throughout the World: Europe, 2016.

18 The cross-period comparison is designed methodologically to account for potential impacts from the crisis. Moreover, availability of the data leads us choose these periods.

19 Theodoropoulou, S. (2018). Drifting into Labour Market Insecurity? Labour Market Reforms in Europe after 2010. ETUI Research Paper - Working Paper 2018.03.

20 Basic labor market statistics and the author's calculation of descriptive statistics are in line with the justification of EU member state selection. Detailed information on basic labor market statistics and descriptive statistics are available on request.

21 Kupets, O. (2006). Determinants of unemployment duration in Ukraine. Journal of Comparative Economics, 34(2), 228- 
Table 1: Descriptive Statistics

\begin{tabular}{|c|c|c|c|c|c|c|}
\hline & \multicolumn{3}{|c|}{$2006-2009$} & \multicolumn{3}{|c|}{$2011-2014$} \\
\hline & All & ST & Non-ST & All & ST & Non-ST \\
\hline & $\begin{array}{c}\text { Mean } \\
\text { (Std.Dev) }\end{array}$ & $\begin{array}{c}\text { Mean } \\
\text { (Std.Dev) }\end{array}$ & $\begin{array}{c}\text { Mean } \\
\text { (Std.Dev) }\end{array}$ & $\begin{array}{c}\text { Mean } \\
\text { (Std.Dev) }\end{array}$ & $\begin{array}{c}\text { Mean } \\
\text { (Std.Dev) }\end{array}$ & $\begin{array}{c}\text { Mean } \\
\text { (Std.Dev) }\end{array}$ \\
\hline \multicolumn{7}{|l|}{ Turkey } \\
\hline $\begin{array}{l}\text { Unemployment } \\
\text { duration }\end{array}$ & $\begin{array}{l}34.901 \\
(10.13) \\
\end{array}$ & $\begin{array}{l}36.487 \\
(9.46) \\
\end{array}$ & $\begin{array}{l}34.824 \\
(10.15) \\
\end{array}$ & $34.149(10.10)$ & $35.119(9.66)$ & $\begin{array}{l}34.063 \\
(10.14) \\
\end{array}$ \\
\hline $\begin{array}{l}\text { Transition from } \\
\text { unemployment }\end{array}$ & $\begin{array}{l}0.002 \\
(0.05)\end{array}$ & $0.001(0.03)$ & $\begin{array}{l}0.003 \\
(0.05) \\
\end{array}$ & $0.002(0.05)$ & $0.0002(0.02)$ & $\begin{array}{l}0.002 \\
(0.05)\end{array}$ \\
\hline $\begin{array}{l}\text { Total social transfer } \\
\text { payments }\end{array}$ & $\begin{array}{l}2796.316 \\
(4934.40)\end{array}$ & & & $\begin{array}{l}5890.811 \\
(7140.47) \\
\end{array}$ & & \\
\hline Education & $8.586(3.74)$ & $9.971(4.41)$ & $\begin{array}{l}8.513 \\
(3.69) \\
\end{array}$ & $9.802(4.21)$ & $9.525(4.19)$ & $\begin{array}{l}9.151 \\
(3.83) \\
\end{array}$ \\
\hline Age & $30.149(11.66)$ & $32.548(9.55)$ & $30.035(11.74)$ & $36.373(8.22)$ & $\begin{array}{l}38.898 \\
(12.22)\end{array}$ & $\begin{array}{l}29.483 \\
(10.93)\end{array}$ \\
\hline Marital Status & $0.467(0.50)$ & $0.352(0.48)$ & $0.472(0.50)$ & $0.743(0.44)$ & $0.637(0.48)$ & $0.432(0.50)$ \\
\hline Gender & $0.151(0.36)$ & $0.319(0.47)$ & $0.143(0.35)$ & $0.198(0.40)$ & $0.262(0.44)$ & $0.155(0.36)$ \\
\hline Observations & 1127992 & 51503 & 1076489 & 2006217 & 164148 & 1842069 \\
\hline \multicolumn{7}{|l|}{ The Netherlands } \\
\hline $\begin{array}{l}\text { Unemployment } \\
\text { duration }\end{array}$ & $31.624(10.24)$ & $\begin{array}{l}30.348 \\
(10.49) \\
\end{array}$ & 33.035 (9.77) & $33.624(10.31)$ & $\begin{array}{l}34.058 \\
(10.27) \\
\end{array}$ & $\begin{array}{l}32.954 \\
(10.34) \\
\end{array}$ \\
\hline $\begin{array}{l}\text { Transition from } \\
\text { unemployment }\end{array}$ & $0.001(0.02)$ & $0.0003(0.02)$ & $0.0009(0.03)$ & $0.001(0.03)$ & $0.0003(0.02)$ & $\begin{array}{l}0.002 \\
(0.05)\end{array}$ \\
\hline $\begin{array}{l}\text { Total social transfer } \\
\text { payments }\end{array}$ & $\begin{array}{c}13897.5 \\
(11500.95)\end{array}$ & & & $\begin{array}{c}17583.64 \\
(13452.51) \\
\end{array}$ & & \\
\hline Education & $12.734(2.91)$ & $13.262(2.67)$ & $12.151(3.05)$ & $13.660(2.62)$ & $13.943(2.55)$ & $13.214(2.67)$ \\
\hline Age & 48.978 (11.94) & $\begin{array}{l}51.762 \\
(11.15)\end{array}$ & $45.901(12.03)$ & 49.351 (11.72) & $\begin{array}{l}51.314 \\
(11.04)\end{array}$ & $\begin{array}{l}46.326 \\
(12.09)\end{array}$ \\
\hline Marital Status & $0.226(0.42)$ & $0.350(0.48)$ & $0.088(0.28)$ & $0.305(0.46)$ & $0.431(0.50)$ & $0.111(0.31)$ \\
\hline Gender & $0.611(0.49)$ & $0.548(0.50)$ & $0.682(0.47)$ & $0.531(0.50)$ & $0.476(0.50)$ & $0.614(0.49)$ \\
\hline Observations & 211797 & 111166 & 100631 & 402520 & 244075 & 158445 \\
\hline \multicolumn{7}{|l|}{ Spain } \\
\hline $\begin{array}{l}\text { Unemployment } \\
\text { duration }\end{array}$ & $34.917(10.15)$ & $35.887(9.83)$ & $34.108(10.35)$ & $34.149(9.92)$ & $\begin{array}{l}33.977 \\
(10.04) \\
\end{array}$ & $\begin{array}{l}34.336 \\
(9.783) \\
\end{array}$ \\
\hline $\begin{array}{l}\text { Transition from } \\
\text { unemployment }\end{array}$ & $0.004(0.06)$ & $0.002(0.04)$ & $0.005(0.07)$ & $0.007(0.08)$ & $0.004(0.07)$ & $0.010(0.01)$ \\
\hline $\begin{array}{l}\text { Total social transfer } \\
\text { payments }\end{array}$ & $\begin{array}{l}5047.822 \\
(4336.41) \\
\end{array}$ & & & $\begin{array}{l}5695.729 \\
(8195.03) \\
\end{array}$ & & \\
\hline Education & $9.919(3.24)$ & $9.897(3.27)$ & $9.938(3.22)$ & $10.934(3.34)$ & $10.912(3.32)$ & $10.959(3.37)$ \\
\hline Age & $39.666(13.37)$ & $\begin{array}{l}43.687 \\
(12.86) \\
\end{array}$ & $36.307(12.85)$ & $40.437(12.46)$ & $\begin{array}{l}44.526 \\
(11.41) \\
\end{array}$ & $\begin{array}{l}35.983 \\
(12.02) \\
\end{array}$ \\
\hline
\end{tabular}

247., Doğan, F. İ. (2019). UNEMPLOYMENT BENEFITS AND UNEMPLOYMENT DURATION IN FRANCE AND

POLAND. Marmara Üniversitesi Avrupa Topluluğu Enstitüsü Avrupa Araştırmaları Dergisi, 27(1), 191-216. 


\begin{tabular}{|l|c|c|c|c|c|c|}
\hline Marital Status & $0.470(0.50)$ & $0.532(0.50)$ & $0.418(0.49)$ & $0.465(0.50)$ & $0.553(0.50)$ & $0.369(0.48)$ \\
\hline Gender & $0.530(0.50)$ & $0.492(0.50)$ & $0.563(0.50)$ & $0.423(0.49)$ & $0.412(0.49)$ & $0.436(0.50)$ \\
\hline Observations & 1481296 & 674207 & 807089 & 2584165 & 1347107 & 1237058 \\
\hline
\end{tabular}

Source: SILC by TurkStat, EU-SILC by EUROSTAT.

1. Amounts are in TL for Turkey and EUR for the EU countries.

2. This article builds on author's Ph.D. dissertation entitled "The Impact of Social Transfers on Labor Supply: A Comparative Analysis of Turkey and the EU”. Also, this study is the extended version of Doğan (2019).

Table 1 presents basic descriptive statistics regarding social transfers in the three labor market areas across the two periods under investigation. ${ }^{22}$

\section{Empirical Methodology}

The dependent variable in this research note is the rate of exit from unemployment-namely, the transition from a state of being "unemployed" to being "employed". Statistical analysis of unemployment spells has increasingly come to rely on models of survival/duration models, such as the hazard function model. This is because the underlying data is not distributed normally and there are issues of censoring, time-variable covariation and duration dependence ${ }^{23}$ that preclude using standard regression approaches ${ }^{24}$. The hazard model allows us to observe each individual, $i$, and their unemployment durations by simply looking at the unemployment spells, $t . t_{i}=\left(t_{i}^{c}\right)$, where $c$ is the number of the spell. The general form of the model is

$$
h_{i}(t)=\left(\beta_{0}+x_{i} \beta_{x}\right) t
$$

where $i$ represents each individual and $\beta$ is the estimated coeffiecient of the model. $X_{\mathrm{i}}$ refers to covariates set of individuals. Further analysis is provided with the parametric model, more specifically the Accelerated Failure Time (AFT) model. The parametric hazard model is represented in the form of

$$
\ln \left(t_{i}\right)=\beta_{0}+\mathrm{x}_{\mathrm{i}} \beta_{\mathrm{x}}+\epsilon_{\mathrm{i}}
$$

which is disaggregates the proportional hazard model and is written as

$$
h\left(\mathrm{t} \mid x_{i}\right)=\mathrm{h}_{0}(\mathrm{t}) \exp \left(\beta_{0}+\mathrm{x}_{\mathrm{i}} \beta_{\mathrm{x}}\right)
$$

22 In Turkey, social transfer recipients spend, on average, more time unemployed than those not in receipt of benefits in both periods. In the Netherlands, benefit recipients are unemployed for four fewer months than non-recipients, on average, in the first period. In the second period, however, benefit recipients spend two months longer unemployed than non-recipients. In Spain, benefit recipients spend longer unemployed than those not in receipt in the 2006-09 period but the durations for both groups are the same in the 2011-14 period.

23 Doğan, F. İ. (2019). UNEMPLOYMENT BENEFITS AND UNEMPLOYMENT DURATION IN FRANCE AND POLAND. Marmara Üniversitesi Avrupa Topluluğu Enstitüsü Avrupa Araştırmaları Dergisi, 27(1), 191-216.

24 For more detail, see Cox, D. R. (1972). Regression models and life-tables. Journal of the Royal Statistical Society. Series B (Methodological), Vol. 34, No. 2. (1972), pp. 187-220., Ham, J. C. and Rea, A. S. (1987), "Unemployment Insurance and Male Unemployment Duration in Canada," Journal of Labor Economics, 5, 325-353., Jenkins, S. P. (1995), "Easy Estimation Methods for Discrete-time Duration Models", Oxford Bulletin of Economics and Statistics, 57(1), 129-138. 
Cleves $(2008)^{25}$ states that $\ln (\mathrm{t})$ includes the proportional hazard interpretation; therefore, parametric proportional hazard models are written in the form

$$
h_{i}(t)=\mathrm{h}_{0}(\mathrm{t}) \exp \left(\beta_{0}+\mathrm{x}_{\mathrm{i}} \beta_{\mathrm{x}}\right)
$$

The semiparametric Cox proportional hazard model with an unrestricted baseline is the standard estimation method used in empirical analysis of unemployment duration. This is because Parametric proportional hazard ( $\mathrm{PPH}$ ) models are similar (but not identical) to Cox $\mathrm{PH}$ models, since $\mathrm{PPH}$ is a parametric version of Cox PH. Besides these similarities, the main difference is the assumption that the baseline hazard function has a specific distribution, whereas the data is omitted in the $\mathrm{PPH}$ model. The Cox PH model does not include that restriction. Moreover, in the PPH model, maximum likelihood estimates the coefficients, while it is done by partial likelihood in the Cox PH model ${ }^{26}$. It is accepted that the probability distribution is limited in the PPH model; thus, AFT models are used in those cases. In addition to these, when proportional hazard assumptions are violated, the AFT model is the appropriate method to apply. That is why AFT models are used for further analyses in this study ${ }^{27}$. The effects of the explanatory variables are reported as survival time in AFT models, which are written as

$$
\ln \left(t_{i}\right)=x_{i} \beta_{x}+\epsilon_{i}
$$

and the failure time $t_{i}$ is

$$
\tau_{i}=\exp \left(-x_{i} \beta_{x}\right) t_{i}
$$

where $\exp \left(-x_{i} \beta_{x}\right)$ is known as an acceleration parameter. Since AFT models report survival timeinstead of hazard ratios - the acceleration parameter whereby $\exp \left(-x_{i} \beta_{x}\right)>1$, then the expected event is more likely to happen earlier, whereas if $\exp \left(-x_{i} \beta_{x}\right)<1$, the expected event is more likely to happen later. So, if $\tau_{i}=\exp \left(-x_{i} \beta_{x}\right) t_{i}$, then $t_{i}=\exp \left(-x_{i} \beta_{x}\right) \tau_{i}{ }^{28}$ resulting in

$$
\ln \left(t_{i}\right)=x_{i} \beta_{x}+\ln \left(\tau_{i}\right)
$$

Economic theory posits that "premature" labor force exit-typically reflected in early retirementhas a deleterious impact on total factor productivity. Economists have long noted that the labor market is subject to a significant amount of "churn", in which workers leaving one job quickly take up a new position after a short period of unemployment. However, a certain proportion of those who lose their jobs will either remain permanently unemployed or enter and exit the labor market

25 Cleves, M. (2008). An introduction to survival analysis using Stata. Stata Press.

26 Qi, J. (2009). Comparison of proportional hazards and accelerated failure time models (Doctoral dissertation).

27 The AFT model includes five different types of distribution: exponential, Weibull, lognormal, loglogistic, and gamma. Since there are five different models, the appropriate one is selected according to the Akaike information criterion (AIC). AIC $=-2 l+2(k+c)$, where 1 represents the log likelihood, the number of covariates is shown by $\mathrm{k}$, and $\mathrm{c}$ is the number of model-specific ancillary parameters. The lowest AIC leads us to the proper model, but one must be kept in mind that generalized gamma models include exponential, Weibull, and lognormal distributions as special cases. Therefore, these are nested in gamma models. That is why estimation results of the gamma distribution are not reported.

28 For more detail, see Doğan, F. İ. (2019). UNEMPLOYMENT BENEFITS AND UNEMPLOYMENT DURATION IN FRANCE AND POLAND. Marmara Üniversitesi Avrupa Topluluğu Enstitüsü Avrupa Araştırmaları Dergisi, 27(1), $191-216$. 
intermittently thereafter ${ }^{29}$. The transition from unemployment to employment (and vice versa) is affected not only by the labor market conditions but also by socioeconomic and demographic factors ${ }^{30}$. To be able to see the "isolated net effect of time out of work on the hazard of leaving unemployment," the set of independent variables is included in the analyses ${ }^{31}$. In line with previous studies, the theoretical background ${ }^{32}$ and availability of the dataset are included as independent variables. These comprise gender (female, male), age dummies of the individuals, marital status (married, otherwise), the education level attained dummies (lower, vocational, higher), the number of earners in the household, the unemployment rate ${ }^{33}$ (according to the age groups of young, middle, and $\mathrm{old}^{34}$ ), occupation (managers, professionals, technicians, workers, elementary occupations), and the predicted wage of the individuals. To estimate individual wages ${ }^{35}$, the present study adopts Mincer's (1958) ${ }^{36}$ earnings function model, which is formed as follows:

$$
\ln \text { wage }=f(s, x)=\text { lnwage }_{0}+\rho s+\beta_{1} x+\beta_{2} x^{2}
$$

where wage is the income, $s$ is the years of schooling, and $x$ denotes years potential of labor market experience. Following Mincer's approach, this paper generates the estimated wage as:

$$
\begin{gathered}
\ln (w)=f(\text { gender, age, education, occupation, sector in occupation, region, year }) \\
\begin{array}{c}
\ln (w)= \\
\beta_{0}+\beta_{1} \text { gender }+\beta_{3} \text { age }+\beta_{4} \text { edu }+\beta_{5} \text { occ }+\beta_{6} \text { sector }+\beta_{7} \text { region }+\beta_{8} \text { year } \\
+u_{i}
\end{array}
\end{gathered}
$$

where gender takes the value of 1 if female and 0 otherwise; age is the age of each individual; education comprises a set of six dummy variables: not graduated, primary school graduates, secondary school graduates, high school graduates, vocational high school graduates; ${ }^{37}$ occupation (ISCO-08) comprises a set of five dummy variables: managers, professionals, technicians, workers, and elementary occupations; sectoral information (economic activity code) ${ }^{38}$ comprises various

29 Contini, B., \& Quaranta, R. (2017). Explaining Non-Employment Magnitude and Duration: The Case of Italy.

30 Contini, B., \& Quaranta, R. (2017). Explaining Non-Employment Magnitude and Duration: The Case of Italy., Yildirim, J., \& Dal, S. (2016). Social Transfers and Labor Force Participation Relation in Turkey: A Bivariate Probit Analysis. Emerging Markets Finance and Trade, 52(7), 1515-1527.

31 Kupets, O. (2006). Determinants of unemployment duration in Ukraine. Journal of Comparative Economics, 34(2), 228 247.

32 See Devine, T. J., \& Kiefer, N. M. (1991). Empirical labor economics: the search approach. Oxford University Press on Demand.

33 Since TurkStat SILC four-year panel data does not include regional information, the unemployment rate is calculated according to age groups.

34 Age is determined as $15-29=$ young, $30-49=$ middle, 50 and over $=$ old.

35 Estimated wages are included in the model as predicted wage of the individuals.

36 Mincer, J. (1958). Investment in human capital and personal income distribution. Journal of political economy, 66(4), 281-302.

37 EU-SILC dataset for 2006-09 does not provide information regarding vocational high school, which is therefore excluded for the EU countries in the 2006-09 period.

38 The EU-SILC dataset does not cover sectoral information therefore it is not included for the EU countries. 
dummy variables and is taken from Nace Rev.1 and Nace Rev.2 accordingly; region ${ }^{39}$ comprises $^{2}$ several dummy variables, and finally; year is the yearly dummy variables.

\section{Empirical Findings}

After deriving and estimating the parameters, it was possible to see and show how with just a few parameters one can determine the impact of the social transfers on the labor supply with the given variables. The results for exiting from unemployment to employment are reported in table $2^{40}$. The figures reported are the estimated coefficients indicating the impact of each independent variable on exit from unemployment. Three regressions were run in the analysis for different models. The base model [regressor (1)] includes only gender, education, and predicted wage variables. The second model [regressor (2)] comprises all the control variables except social transfers. The third model [regressor (3)] includes the total range of social transfers.

Table 2: AFT Hazard Model Summary Estimations

\begin{tabular}{|l|c|c|c|c|c|c|}
\hline & \multicolumn{3}{|c|}{$\mathbf{2 0 0 6}-\mathbf{2 0 0 9}$} & \multicolumn{3}{c|}{$\mathbf{2 0 1 1 - 2 0 1 4}$} \\
\hline & $(\mathbf{1})$ & $(\mathbf{2})$ & $(\mathbf{3})$ & $(\mathbf{1})$ & $(\mathbf{2})$ & $(3)$ \\
\hline Turkey & LL & LL & LL & LL & LL & LL \\
\hline ST & & & $0.502^{* * *}$ & & & $0.685^{* * *}$ \\
\hline & & & $(0.076)$ & & & $(0.070)$ \\
\hline Female & $0.321^{* * *}$ & $0.302^{* * *}$ & $0.284^{* * *}$ & $0.657^{* * *}$ & $0.550^{* * *}$ & $0.510^{* * *}$ \\
\hline & $(0.028)$ & $(0.029)$ & $(0.029)$ & $(0.033)$ & $(0.033)$ & $(0.033)$ \\
\hline Lower_edu & $0.462^{* * *}$ & $0.426^{* * *}$ & $0.433^{* * *}$ & $0.426^{* * *}$ & $0.233^{* * *}$ & $0.238^{* * *}$ \\
\hline & $(0.022)$ & $(0.022)$ & $(0.022)$ & $(0.019)$ & $(0.019)$ & $(0.019)$ \\
\hline Higher_edu & $0.634^{* * *}$ & $0.649^{* * *}$ & $0.622^{* * *}$ & $0.969^{* * *}$ & $0.843^{* * *}$ & $0.841^{* * *}$ \\
\hline & $(0.047)$ & $(0.049)$ & $(0.049)$ & $(0.048)$ & $(0.047)$ & $(0.047)$ \\
\hline Pre_wage & $0.084^{* * *}$ & $0.014^{*}$ & $0.016^{* *}$ & $0.099^{* * *}$ & $0.013^{* *}$ & $0.012^{* *}$ \\
\hline & $(0.004)$ & $(0.007)$ & $(0.007)$ & $(0.003)$ & $(0.006)$ & $(0.006)$ \\
\hline Marital_sta & & $-0.078^{* * *}$ & $-0.069^{* * *}$ & & $0.778^{* * *}$ & $0.762^{* * *}$ \\
\hline & & $(0.023)$ & $(0.023)$ & & $(0.025)$ & $(0.025)$ \\
\hline Young & & $-2.811^{* * *}$ & $-2.715^{* * *}$ & & $-1.826^{* * *}$ & $-1.740^{* * *}$ \\
\hline & & $(0.153)$ & $(0.153)$ & & $(0.100)$ & $(0.100)$ \\
\hline Old & & $2.352^{* * *}$ & $2.343^{* * *}$ & & $1.306^{* * *}$ & $1.216^{* * *}$ \\
\hline & & $(0.204)$ & $(0.204)$ & & $(0.073)$ & $(0.073)$ \\
\hline Technicians & & $0.794^{* * *}$ & $0.776^{* * *}$ & & $1.194^{* * *}$ & $1.186^{* * *}$ \\
\hline & & $(0.130)$ & $(0.130)$ & & $(0.187)$ & $(0.187)$ \\
\hline Pro & & 0.087 & 0.099 & & $1.219^{* * *}$ & $1.227^{* * *}$ \\
\hline & & $(0.121)$ & $(0.121)$ & & $(0.267)$ & $(0.267)$ \\
\hline Elem_occ & & $0.209^{* * *}$ & $0.202^{* * *}$ & & $0.492^{* * *}$ & $0.497^{* * *}$ \\
\hline & $(0.050)$ & $(0.050)$ & & $(0.044)$ & $(0.044)$ \\
\hline
\end{tabular}

39 Region variable is only included in the analyses concerning Spain. The datasets do not cover region information for Turkey and the Netherlands.

40 Tables showing full version of the AFT hazard model estimation results for each country are available upon request. 
Fadime İrem DOĞAN

\begin{tabular}{|c|c|c|c|c|c|c|}
\hline Workers & & $0.554^{* * *}$ & $0.541^{* * *}$ & & $0.567^{\star \star *}$ & $0.559^{* * *}$ \\
\hline & & $(0.049)$ & $(0.048)$ & & $(0.045)$ & $(0.045)$ \\
\hline \multirow[t]{2}{*}{ No of earner } & & $-0.130^{\star * *}$ & $-0.127^{\star * *}$ & & $-0.138^{\star * *}$ & $-0.136^{* * *}$ \\
\hline & & $(0.006)$ & $(0.006)$ & & $(0.006)$ & $(0.006)$ \\
\hline \multirow[t]{2}{*}{ Un_rate } & & $32.484^{* * *}$ & $31.504^{* * *}$ & & $29.408^{* * *}$ & $28.458^{\star * *}$ \\
\hline & & $(1.659)$ & $(1.658)$ & & $(1.177)$ & $(1.172)$ \\
\hline \multirow[t]{2}{*}{ Constant } & $5.580^{* * *}$ & $4.007^{* * *}$ & $4.030^{* * *}$ & $5.659^{* * *}$ & $3.542^{* * *}$ & $3.583^{* * *}$ \\
\hline & $(0.038)$ & $(0.090)$ & $(0.090)$ & $(0.033)$ & $(0.073)$ & $(0.073)$ \\
\hline \multirow[t]{2}{*}{ Observations } & 1127992 & 1127992 & 1127992 & 2006217 & 2006217 & 2006217 \\
\hline & $(1)$ & $(2)$ & (3) & $(1)$ & $(2)$ & (3) \\
\hline The Netherlands & $\mathrm{LL}$ & LL & LL & LN & $\mathrm{LL}$ & $\mathrm{LL}$ \\
\hline \multirow[t]{2}{*}{$S T$} & & & $-0.395^{\star *}$ & & & $0.405^{\star * *}$ \\
\hline & & & $(0.167)$ & & & $(0.0710)$ \\
\hline \multirow[t]{2}{*}{ Female } & $4.811^{\star * *}$ & $2.000^{* * *}$ & $1.939^{* * *}$ & $1.547^{\star * *}$ & $0.948^{* * *}$ & $0.908^{\star * \star}$ \\
\hline & $(0.432)$ & $(0.311)$ & $(0.311)$ & $(0.101)$ & $(0.0847)$ & $(0.0805)$ \\
\hline \multirow[t]{2}{*}{ Lower_edu } & $4.715^{\star * *}$ & $4.312^{* * *}$ & $4.404^{* * *}$ & $1.410^{* * *}$ & $0.430^{* * *}$ & $0.348^{\star * *}$ \\
\hline & $(0.395)$ & $(0.362)$ & $(0.368)$ & $(0.0878)$ & $(0.0646)$ & $(0.0630)$ \\
\hline \multirow[t]{2}{*}{ Higher_edu } & -0.430 & $1.718^{\star * *}$ & $1.815^{* * *}$ & $1.380^{* * *}$ & $1.282^{* * *}$ & $1.312^{* * *}$ \\
\hline & $(0.345)$ & $(0.377)$ & $(0.378)$ & $(0.231)$ & $(0.263)$ & $(0.254)$ \\
\hline \multirow[t]{2}{*}{ Pre_wage } & $2.222^{* * *}$ & $0.809^{* * *}$ & $0.791^{* * *}$ & $0.496^{* * *}$ & $0.218^{* * *}$ & $0.182^{* * *}$ \\
\hline & $(0.202)$ & $(0.138)$ & $(0.138)$ & $(0.0300)$ & $(0.0256)$ & $(0.0241)$ \\
\hline \multirow[t]{2}{*}{ Marital_sta } & & 10.92 & 11.05 & & 9.994 & 9.021 \\
\hline & & $(911.0)$ & $(867.8)$ & & $(808.1)$ & $(419.0)$ \\
\hline \multirow[t]{2}{*}{ Young } & & 17.41 & 17.96 & & 10.60 & 9.605 \\
\hline & & $(779.9)$ & $(858.0)$ & & $(1,301)$ & $(615.2)$ \\
\hline \multirow[t]{2}{*}{ Old } & & $5.584^{* * *}$ & $5.973^{* * *}$ & & $0.962^{* * *}$ & $0.818^{\star * *}$ \\
\hline & & $(0.723)$ & $(0.758)$ & & $(0.111)$ & $(0.107)$ \\
\hline \multirow[t]{2}{*}{ Technicians } & & 12.20 & 12.43 & & $1.381^{* * *}$ & $1.318^{* * *}$ \\
\hline & & $(3,096)$ & $(3,134)$ & & $(0.227)$ & $(0.221)$ \\
\hline \multirow[t]{2}{*}{ Pro } & & 8.787 & 9.188 & & $0.850^{* * *}$ & $0.902^{* * *}$ \\
\hline & & $(2,678)$ & $(2,624)$ & & $(0.320)$ & $(0.313)$ \\
\hline \multirow[t]{2}{*}{ Elem_occ } & & 6.403 & 6.643 & & $0.480^{* * *}$ & $0.559^{* * *}$ \\
\hline & & $(3,443)$ & $(3,608)$ & & $(0.176)$ & $(0.171)$ \\
\hline \multirow[t]{2}{*}{ Workers } & & 7.194 & 7.708 & & $0.760^{* * *}$ & $0.814^{* * *}$ \\
\hline & & $(992.3)$ & $(1,021)$ & & $(0.130)$ & $(0.126)$ \\
\hline \multirow[t]{2}{*}{ No of earner } & & 11.05 & 11.11 & & $0.430^{* * *}$ & $0.323^{* * *}$ \\
\hline & & $(1,032)$ & $(1,104)$ & & $(0.105)$ & $(0.104)$ \\
\hline \multirow[t]{2}{*}{ Un_rate } & & $-263.2^{* * *}$ & $-285.9^{\star * *}$ & & $-21.45^{\star * *}$ & $-16.97^{* * *}$ \\
\hline & & $(38.37)$ & $(41.09)$ & & $(4.798)$ & $(4.671)$ \\
\hline \multirow[t]{2}{*}{ Constant } & $-3.011^{\star * *}$ & $3.940^{* * *}$ & $4.345^{* * *}$ & $5.156^{* * *}$ & $5.164^{* * *}$ & $5.059^{* * *}$ \\
\hline & $(0.613)$ & $(0.790)$ & $(0.825)$ & $(0.123)$ & $(0.176)$ & $(0.171)$ \\
\hline \multirow[t]{2}{*}{ Observations } & 211797 & 211797 & 211797 & 402520 & 402520 & 402520 \\
\hline & $(1)$ & $(2)$ & (3) & $(1)$ & $(2)$ & (3) \\
\hline Spain & LN & LL & LL & $\mathrm{W}$ & $\mathrm{W}$ & $\mathrm{W}$ \\
\hline$S T$ & & & $0.195^{\text {***}}$ & & & $0.0937^{\star * *}$ \\
\hline
\end{tabular}




\begin{tabular}{|c|c|c|c|c|c|c|}
\hline & & & $(0.015)$ & & & $(0.00750)$ \\
\hline \multirow[t]{2}{*}{ Female } & $0.705^{\star * *}$ & $0.244^{* * *}$ & $0.262^{* * *}$ & $0.798^{\star * *}$ & $0.532^{* * *}$ & $0.533^{\star * *}$ \\
\hline & $(0.033)$ & $(0.032)$ & $(0.031)$ & $(0.0118)$ & $(0.0116)$ & $(0.0116)$ \\
\hline \multirow[t]{2}{*}{ Lower_edu } & $8.181^{\star * *}$ & $0.598^{\star * *}$ & $0.587^{\star * *}$ & $0.403^{\star * *}$ & $0.132^{\star * *}$ & $0.124^{\star * \star}$ \\
\hline & $(0.063)$ & $(0.062)$ & $(0.061)$ & $(0.00791)$ & $(0.00804)$ & $(0.00805)$ \\
\hline \multirow[t]{2}{*}{ Higher_edu } & $7.710^{* * *}$ & $-0.146^{*}$ & $-0.146^{\star *}$ & $0.528^{\star * *}$ & $0.393^{* * *}$ & $0.400^{\star * *}$ \\
\hline & $(0.077)$ & $(0.075)$ & $(0.074)$ & $(0.0181)$ & $(0.0186)$ & $(0.0186)$ \\
\hline \multirow[t]{2}{*}{ Pre_wage } & $0.193^{\star * *}$ & $0.322^{* * *}$ & $0.317^{* * *}$ & $0.129^{* * *}$ & $0.0318^{* * *}$ & $0.0270^{* * *}$ \\
\hline & $(0.006)$ & $(0.028)$ & $(0.027)$ & $(0.00202)$ & $(0.00247)$ & $(0.00250)$ \\
\hline \multirow[t]{2}{*}{ Marital_sta } & & $-0.033^{*}$ & $-0.035^{\star *}$ & & 0.00424 & -0.00828 \\
\hline & & $(0.017)$ & $(0.017)$ & & $(0.00734)$ & $(0.00742)$ \\
\hline \multirow[t]{2}{*}{ Young } & & $-3.376^{\star * *}$ & $-3.238^{\star * *}$ & & $-1.014^{* * *}$ & $-0.993^{* * *}$ \\
\hline & & $(0.076)$ & $(0.075)$ & & $(0.0606)$ & $(0.0606)$ \\
\hline \multirow[t]{2}{*}{ Old } & & $-0.246^{\star * *}$ & $-0.245^{\star * *}$ & & $0.506^{\star * *}$ & $0.482^{\star * *}$ \\
\hline & & $(0.022)$ & $(0.022)$ & & $(0.0126)$ & $(0.0127)$ \\
\hline \multirow[t]{2}{*}{ Technicians } & & -0.083 & -0.077 & & $1.460^{* * *}$ & $1.425^{\star * *}$ \\
\hline & & $(0.051)$ & $(0.050)$ & & $(0.0633)$ & $(0.0633)$ \\
\hline \multirow[t]{2}{*}{ Pro } & & $-1.897^{* * *}$ & $-1.860^{* * *}$ & & $1.073^{* * *}$ & $1.062^{* * *}$ \\
\hline & & $(0.160)$ & $(0.158)$ & & $(0.0755)$ & $(0.0755)$ \\
\hline \multirow[t]{2}{*}{ Elem_occ } & & $-2.300^{* * *}$ & $-2.262^{* * *}$ & & $0.486^{* * *}$ & $0.473^{\star * *}$ \\
\hline & & $(0.188)$ & $(0.185)$ & & $(0.0128)$ & $(0.0128)$ \\
\hline \multirow[t]{2}{*}{ Workers } & & $-2.078^{* * *}$ & $-2.053^{* * *}$ & & $0.497^{* * *}$ & $0.484^{* * *}$ \\
\hline & & $(0.166)$ & $(0.163)$ & & $(0.00967)$ & $(0.00967)$ \\
\hline \multirow[t]{2}{*}{ No of earner } & & $0.402^{* * *}$ & $0.392^{* * *}$ & & $0.0619^{* * *}$ & $0.0601^{\star * *}$ \\
\hline & & $(0.012)$ & $(0.012)$ & & $(0.00449)$ & $(0.00449)$ \\
\hline \multirow[t]{2}{*}{ Un_rate } & & $35.421^{\star * *}$ & $34.426^{\star * *}$ & & $6.409^{* * *}$ & $6.383^{* * *}$ \\
\hline & & $(0.802)$ & $(0.795)$ & & $(0.269)$ & $(0.269)$ \\
\hline \multirow[t]{2}{*}{ Constant } & 0.061 & $3.940^{* * *}$ & $4.345^{\star * *}$ & $4.649^{* * *}$ & $3.453^{* * *}$ & $3.459^{* * *}$ \\
\hline & $(0.444)$ & $(0.790)$ & $(0.825)$ & $(0.0105)$ & $(0.0520)$ & $(0.0520)$ \\
\hline Observations & 183824 & 183824 & 183824 & 2584165 & 2584165 & 2584165 \\
\hline
\end{tabular}

1-Standard errors are shown in parentheses.

$2-^{*}$ Significant at $10 \%{ }^{* *}$ significant at $5 \%$; ${ }^{* *}$ significant at $1 \%$.

3-ST: Total Social Transfers, E: exponential, W: Weibull, LN: log-normal, LL: log - logistic.

4-This article builds on author's Ph.D. dissertation entitled "The Impact of Social Transfers on Labor Supply: A

Comparative Analysis of Turkey and the EU”. Also, this study is the extended version of Doğan (2019).

Analysis covering all countries is presented in table 2. In Turkey, recipients may receive transfers long after they have ceased being unemployed. Moreover, benefits include a range of different transfer forms (education, disability, old age, survivors, etc.) and the full range must be taken into account since all bring some kind of income into the household and thus impact individual exit behavior. Turkey's population has grown significantly in recent decades as has the level of educational attainment, resulting in a large pool of overqualified labor for recruitment. This has boosted the reservation wage, as labor mismatch theory predicts. Less-educated individuals may look for a job 
with a lower reservation wage, since they have lower skills compared to well-educated individuals. Moreover, the rapid increase in the unemployment rate forces highly educated people to bid for work in the market at a lower wage. Added to that, with a larger job network, their opportunity cost of unemployment is higher, and they are more likely to be mobile ${ }^{41}$. Education coefficients estimations turn out to be significant in both four-year periods. Low - and high-educated people tend to stay unemployed longer than vocational high school graduates do.

In line with the research concerning Spain, our results suggested that receiving social transfers prolongs the duration of unemployment in both periods. The 1984 Spanish labor market reform created a new form of unemployment without benefits. Benefit-wise, there are outcomes of this reform. Bover et al. $(2002)^{42}$ explains this as the "entitlement effect". They define the entitlement effect as a positive linear relationship of increased benefits, and the utility expectation of unemployment spells with benefits from the future but the opposite for the current time. It basically makes individuals stay unemployed longer. Also, Spain has been dealing with high unemployment for decades. The government and researchers have been trying to understand and tackle the problem. Explanations have been found on both the labor demand and supply sides. Lack of job creation, and generous social transfers (unemployment benefits to be specific) have resulted in a structural high unemployment rate in Spain ${ }^{43}$.

The empirical evidence shows that the impact of social transfers on labor supply differs across countries. In light of the structure of the labor market, consequences vary. Out of the three countries covered in this study, only the Netherlands comes to the forefront. Receiving social transfers shortened the unemployment duration in the Netherlands in the first period. Being the only country with this result, one might ask: Why the Netherlands? There are several possible explanations. First, the Netherlands is one of the only European countries with a flexible and secure labor market modelalso known as the 'flexicurity' model ${ }^{44}$. Social transfer payments are generous in the Netherlands. However, one must take into consideration that this generosity is a result of having a very liberal and elastic labor market, not due to the low unemployment rate. Second, in line with the labor mismatch and overqualified labor problem, unemployed individuals are more likely to wait to re-enter the labor force while receiving unemployment benefits. By providing high amounts of social transfers, the Netherlands may be eliminating the mismatch problem. The third possible explanation may be the high GDP per capita and the number of part-time workers.

41 Kupets, O. (2006). Determinants of unemployment duration in Ukraine. Journal of Comparative Economics, 34(2), 228247.

42 Bover, O., Arellano, M., \& Bentolila, S. (2002). Unemployment duration, benefit duration and the business cycle. The Economic Journal, 112(479), 223-265.

43 Bentolila, S., \& Blanchard, O. J. (1990). Spanish unemployment. Economic Policy, 5(10), 233-281., Ahn, N., \& UgidosOlazabal, A. (1995). Duration of unemployment in Spain: Relative effects of unemployment benefit and family characteristics. Oxford Bulletin of Economics and Statistics, 57(2), 249-264., Toharia, L., \& Jimeno, J. F. (1995). Los hechos básicos del paro. El paro en España, tiene solución. Center for Economic Policy Research., Ahn, N., De La Rica, S., \& Ugidos, A. (1999). Willingness to move for work and unemployment duration in Spain. Economica, 66(263), 335-357.

44 Theodoropoulou, S. (2018). Drifting into Labour Market Insecurity? Labour Market Reforms in Europe after 2010. ETUI Research Paper - Working Paper 2018.03. 


\section{Concluding Remarks}

This article has investigated the impact of social transfers on labor force participation in Turkey and the EU. Through time, various policies and reforms have been conducted both in Turkey and EU Member States regarding the different types of social transfers. The consensus in the literature is that social transfers have a definite impact on labor force participation. Panel of Income and Living Conditions Survey (SILC and EU-SILC) data is taken from TurkStat and Eurostat for the empirical analyses of monthly periods over 2006-09 and 2011-14. The estimation was developed by applying an Accelerated Failure Time (AFT) model. The empirical findings for all three countries in both periods suggest that receiving social transfers lengthens the unemployment duration. In the first period, the more individuals receive social transfers, the shorter their unemployment duration in Dutch labor market. However, the results for the other two reveals that social transfers as a whole extend the unemployment spell. On the other hand, for those in receipt of a variety of transfers (education, disability, old age, survivors, etc.) unemployment duration was longer in the second period for all countries.

In light of these results, this article offers important policy implications. Individuals' labor market participation is clearly highly affected by social transfer durations. In addition, education policies play a vital role in Turkey and the EU, so that the reallocation of investment in training toward oldaged individuals may be the primary policy implication to be drawn. Active Labour Market Policies (ALMPs) have been found to boost the probability of re-employment and to be an effective solution to long-term unemployment ${ }^{45}$. In order to improve labor market outcomes, national governments would be advised to increase ALMP spending as a share of GDP. In order to fight the mismatch problem, governments should undertake initiatives that boost labor market flexibility. Training and retraining programs, redirecting public funds to private and non-profit providers, public job creation, reconstructing human capital via ALMPs, and wage subsidies are all policy measures that would achieve this end ${ }^{46}$.

One promising avenue of research beyond the scope of this study is the question of benefits/transfers and "technological unemployment", a term coined by Keynes $(1930)^{47}$ to capture the idea that technology presents a looming structural feature steadily reducing the demand for human labor over time. With the advent of artificial intelligence and advanced robotics, a growing body of literature has drawn particular attention to the threat ${ }^{48}$. While benefits/transfers feature in the mix of policy

45 World Bank. (2012). World Development Report 2013: Jobs. Washington, DC: World Bank. DOI: 10.1596/978-0-82139575-2., Doğan, F. İ. (2019). UNEMPLOYMENT BENEFITS AND UNEMPLOYMENT DURATION IN FRANCE AND POLAND. Marmara Üniversitesi Avrupa Topluluğu Enstitüsü Avrupa Araştırmaları Dergisi, 27(1), $191-216$.

47 Keynes, J. M. (1930). Economic possibilities for our grandchildren, in (JM Keynes). Essays in persuasion.

48 Autor, D. H., Levy, F., \& Murnane, R. J. (2003). The skill content of recent technological change: An empirical exploration. The Quarterly journal of economics, 118(4), 1279-1333., Goos, M., \& Manning, A. (2007). Lousy and lovely jobs: The rising polarization of work in Britain. The review of economics and statistics, 89(1), 118-133., Brynjolfsson, E., \& McAfee, A. (2014). The second machine age: Work, progress, and prosperity in a time of brilliant technologies. WW Norton \& Company., Michaels, G., Natraj, A., \& Van Reenen, J. (2014). Has ICT polarized skill demand? Evidence from eleven 
responses to technological unemployment in some countries (e.g. Switzerland), further research on the potential for addressing in this issue in a much larger pool of cases would be of great benefit.

\section{References}

ACEMOGLU, D., \& Restrepo, P. (2017). Robots and jobs: Evidence from US labor markets.

AHMAD, N., Svarer, M., \& Naveed, A. (2019). The Effect of Active Labour Market Programmes and Benefit Sanctions on Reducing Unemployment Duration. Journal of Labor Research, 1-28.

AHN, N., \& Ugidos-Olazabal, A. (1995). Duration of unemployment in Spain: Relative effects of unemployment benefit and family characteristics. Oxford Bulletin of Economics and Statistics, 57(2), 249-264.

AHN, N., De La Rica, S., \& Ugidos, A. (1999). Willingness to move for work and unemployment duration in Spain. Economica, 66(263), 335-357.

ALSASUA, J., Bilbao-Ubillos, J., \& Olaskoaga, J. (2007). The EU integration process and the convergence of social protection benefits at national level. International Journal of Social Welfare, 16(4), 297-306.

ARENDT, J. N., \& Kolodziejczyk, C. (2019). The Effects of an Employment Bonus for Long-Term Social Assistance Recipients. Journal of Labor Research, 1-16.

ARRANZ, J. M., \& García-Serrano, C. (2014). Duration and recurrence of unemployment benefits. Journal of Labor Research, 35(3), 271-295.

AUTOR, D. H., Levy, F., \& Murnane, R. J. (2003). The skill content of recent technological change: An empirical exploration. The Quarterly journal of economics, 118(4), 1279-1333.

BARGAIN, O., \& Doorley, K. (2013). Putting structure on the RD design: social transfers and youth inactivity in France.

BENTOLILA, S., \& Blanchard, O. J. (1990). Spanish unemployment. Economic Policy, 5(10), 233-281.

BOVER, O., Arellano, M., \& Bentolila, S. (2002). Unemployment duration, benefit duration and the business cycle. The Economic Journal, 112(479), 223-265.

BRYNJOLFSSON, E., \& McAfee, A. (2014). The second machine age: Work, progress, and prosperity in a time of brilliant technologies. WW Norton \& Company.

CLEVES, M. (2008). An introduction to survival analysis using Stata. Stata Press.

CONTINI, B., \& Quaranta, R. (2017). Explaining Non-Employment Magnitude and Duration: The Case of Italy.

COX, D. R. (1972). Regression models and life-tables. Journal of the Royal Statistical Society. Series B (Methodological), Vol. 34, No. 2. (1972), pp. 187-220.

DĂNĂCICĂ, D. E., \& Mazilescu, R. (2014). Long-term unemployment spells and exit states of men in Romania and Hungary. Procedia Economics and Finance, 8, 236-245.

DEVINE, T. J., \& Kiefer, N. M. (1991). Empirical labor economics: the search approach. Oxford University Press on Demand.

DOĞAN, F. İ. (2019). UNEMPLOYMENT BENEFITS AND UNEMPLOYMENT DURATION IN FRANCE AND POLAND. Marmara Üniversitesi Avrupa Topluluğu Enstitüsü Avrupa Araştırmaları Dergisi, 27(1), 191-216.

EDISIS, A. T. (2016). The Effect of Unemployment Insurance on Temporary Help Services Employment. Journal of Labor Research, 37(4), 484-503.

countries over twenty-five years. Review of Economics and Statistics, 96(1), 60-77., Ford, M. (2015). Rise of the Robots: Technology and the Threat of a Jobless Future. Basic Books., Acemoglu, D., \& Restrepo, P. (2017). Robots and jobs: Evidence from US labor markets. 
ESSER, I., Ferrarini, T., Nelson, K., Palme, J., \& Sjöberg, O. (2013). Unemployment benefits in EU member states.

FILIZ, E. S. (2017). The Effect of Unemployment Insurance Generosity on Unemployment Duration and Labor Market Transitions. LABOUR, 31(4), 369-393.

FORD, M. (2015). Rise of the Robots: Technology and the Threat of a Jobless Future. Basic Books.

GABRIEL, D., Brigitte, S. C., \& Elisabeta, J. (2017). Estimation of Unemployment Duration in Botoşani County Using Survival Analysis. Ovidius University Annals, Series Economic Sciences, 17(1).

GOOS, M., \& Manning, A. (2007). Lousy and lovely jobs: The rising polarization of work in Britain. The review of economics and statistics, 89(1), 118-133.

GRAVERSEN, B. K., \& Van Ours, J. C. (2008). How to help unemployed find jobs quickly: Experimental evidence from a mandatory activation program. Journal of Public economics, 92(10-11), 2020-2035.

HÄGGLUND, A. E., \& Bächmann, A. C. (2017). Fast lane or down the drain? Does the occupation held prior to unemployment shape the transition back to work?. Research in Social Stratification and Mobility, 49, $32-46$.

HAM, J. C. and Rea, A. S. (1987), “Unemployment Insurance and Male Unemployment Duration in Canada," Journal of Labor Economics, 5, 325-353.

HECKMAN, J. (1974). Shadow prices, market wages, and labor supply. Econometrica: journal of the econometric society, 679-694.

ISIKHAN, V. (2009). THE ASPECT OF SOCIAL SERVICES IN TURKEY. Serviço Social \& Realidade, 17(2), 156-171.

JENKINS, S. P. (1995), "Easy Estimation Methods for Discrete-time Duration Models", Oxford Bulletin of Economics and Statistics, 57(1), 129-138.

KEYNES, J. M. (1930). Economic possibilities for our grandchildren, in (JM Keynes). Essays in persuasion.

KRUEGER, A. B., \& Meyer, B. D. (2002). Labor supply effects of social insurance. Handbook of public economics, 4, 2327-2392.

KRUEGER, A. B., \&Pischke, J. S. (1992). The effect of social security on labor supply: A cohort analysis of the notch generation. Journal of labor economics, 10(4), 412-437.

KUPETS, O. (2006). Determinants of unemployment duration in Ukraine. Journal of Comparative Economics, 34(2), 228-247.

LACHOWSKA, M., Meral, M., \& Woodbury, S. A. (2016). Effects of the unemployment insurance work test on long-term employment outcomes. Labour Economics, 41, 246-265.

MEYER, B.D. (1990). Unemployment insurance and unemployment spells. Econometrica 58 (4), 757-782.

MICHAELS, G., Natraj, A., \& Van Reenen, J. (2014). Has ICT polarized skill demand? Evidence from eleven countries over twenty-five years. Review of Economics and Statistics, 96(1), 60-77.

MINCER, J. (1958). Investment in human capital and personal income distribution. Journal of political economy, 66(4), 281-302.

MORRISSEY, T. W. (2017). Child care and parent labor force participation: a review of the research literature. Review of Economics of the Household, 15(1), 1-24.

QI, J. (2009). Comparison of proportional hazards and accelerated failure time models (Doctoral dissertation).

SCHARPF, F. W. (2002). The European social model. JCMS: Journal of Common Market Studies, 40(4), 645670.

SIEBERT, H. (1997). Labor market rigidities: at the root of unemployment in Europe. The Journal of Economic Perspectives, 11(3), 37-54. 
SOCIAL SECURITY ADMINISTRATION. (2016). Social Security Programs Throughout the World: Europe, 2016.

TATSIRAMOS, K., \& Ours, J. C. (2014). Labor market effects of unemployment insurance design. Journal of Economic Surveys, 28(2), 284-311.

THEODOROPOULOU, S. (2018). Drifting into Labour Market Insecurity? Labour Market Reforms in Europe after 2010. ETUI Research Paper - Working Paper 2018.03.

TOHARIA, L., \& Jimeno, J. F. (1995). Los hechos básicos del paro. El paro en España,¿ tiene solución. Center for Economic Policy Research.

WORLD BANK. (2012). World Development Report 2013: Jobs. Washington, DC: World Bank. DOI: 10.1596/978-0-8213-9575-2.

YILDIRIM, J., \& Dal, S. (2016). Social Transfers and Labor Force Participation Relation in Turkey: A Bivariate Probit Analysis. Emerging Markets Finance and Trade, 52(7), 1515-1527. 